\title{
FAMILY CARERS' PERSPECTIVES ON INTEGRATED COMMUNITY CARE IN THE CZECH REPUBLIC
}

\author{
Eva Křižová', Hana Janečková1, Jaromír Běláček² \\ 'Department of Pastoral and Social Work, Protestant Theological Faculty, Charles University, Prague, Czech Republic \\ ${ }^{2}$ General University Hospital in Prague, Prague, Czech Republic
}

\section{SUMMARY}

Aim: The problem of family care for people dependent on another person has only recently become a focus of research. As demand for health and social services has not been adequately met by public service providers, growing attention has been given to informal care and the integration of families within systems of health and social care at the community level. This paper presents the results of a survey on informal carers' views and opinions under the current conditions of social support in the Czech Republic. The survey was based on theoretical concepts of caring societies, deinstitutionalization, refamilization, and integrated community care, and aimed to shed light on caring families' experiences and needs in the Czech Republic.

Methods: Family lay carers completed an original self-administered questionnaire. A convenient sample of 200 family carers was selected.

Results: The survey collected information about the most influential factors in determining whether the families continue to provide care for their relatives in the household. More than $50 \%$ of the caregivers provide care from moral and emotional reasons. Financial problems, risk of losing their jobs, and further deterioration of health of the person they care for emerged as key risk factors, but overall, determination among carers to continue providing care "at any cost" was high (53\%).

Conclusions: Involving local communities and services, e.g. general practitioners (GPs) to a greater extent in the coordination of various social and health services, and in support mechanisms at the juncture between informal and formal care would make it easier for family carers to continue providing long-term care.

Key words: informal caregiving, dependent people, elderly, disability, care allowance, community based integrated health and social care

Address for correspondence: E. Křižová, Protestant Theological Faculty, Charles University, Department of Pastoral and Social Work, Černá 9 , 11555 Prague, Czech Republic. E-mail: krizova@etf.cuni.cz

http://dx.doi.org/10.21101/cejph.a4463

\section{INTRODUCTION}

\section{Concept of Caring Society and Continuity of Care}

In this era of demographic ageing, one of society's challenges is how to care for those who are dependent on others due to physical or mental illness or disability. The development of formal care in many countries over the past decades has given rise to a process of defamilization and the replacement of informal care within the family by care within institutions (1). This process had several aims, one of which was to reduce the housework burden of women and to strengthen individuals' independence from their family; at the same time, the role and responsibilities of the welfare state increased in the field of care for older adults. Institutional care substituted home care where families were least able to provide it, whether due to fragile interpersonal relations or weakened physical capacity. These changes went hand in hand with value shifts in modern society connected with valuing more women's work and their right for equal pay (2). Conflicts between an individual's professional role and his/her role as family carer, the roots of which lie in the deep (emotional) relations between close family members (3), further contributed to this process of defamilization
Since the 1960's, the negative impact of institutional care on individuals, both service users and personnel, has been studied and described by Goffman (4) and other scholars (5-7). Institutional care for older adults has its limits and cannot fully substitute the natural human community of the family home. As a result, the institutional model of care for seniors is now gradually being replaced by systems of support designed to maintain individuals' autonomy and independence in the natural environment as long as possible, in which formal/institutional care and informal care provided by the family supplement each other in integrated practice. Care is not provided by the family alone, but supported adequately by an integrated system of health and social services. This change of perspective has been called refamilization $(1,8)$. Another related theoretical concept is that of the person-centred continuum of care (9). According to this model, service users can obtain the service they need at any time and in any situation. The management and coordination of various types of services and collaboration between households and in-patient and out-patient health and social services is thus of key importance $(10,11)$. Community involvement is fundamental for creating the right conditions for independent living, social inclusion, de-stigmatization, intergenerational cooperation and understanding. This multi-dimensional and multi-sectorial perspective characterizes 
today's "caring society" $(1,2)$. Cooperation between professional services and family carers and provision of support services to family carers are perceived as important factors in the prevention of burnout syndrome and the maltreatment of older adults in the family settings (12). Presumably, this is a key model for preventing the premature institutionalization of older adults in long-term hospitals or caring facilities. Nowadays, informal care is recognized as an important economic resource all over the world in the category of unpaid work. However, despite the support provided to informal carers in many countries, it remains difficult to reconcile work and caring responsibilities, which results in a higher risk of poverty among informal carers (13).

\section{Situation in the Czech Republic}

In 2001, the most important factors that influenced family carers' decisions not to continue providing care, and to move the cared-for person into a care institution in the Czech Republic were: providing care reduces the carer's chances of being (or remaining) employed (34\%); the carer has insufficient skills to provide the specialist care required (33\%); caregiving takes up too much time $(20 \%)$; the care recipient requires live-in care $(16 \%)$; the care represents too great psychological or physical burden $(15 \%$ each, together it makes 30\%). This was mirrored in the feelings of those receiving family care, who did not expect their children to leave their employment in order to care for them. When they encounter a situation of reduced self-sufficiency, the survey found that members of the older generation $(60+$ years) would prefer to move to a care facility (14), while the priority of the middle generation (45-59 years) is to stay in their own household (15). By 2013, however, nearly $80 \%$ of the representative sample of the population surveyed wished to die at home, while only $9 \%$ of respondents preferred to die at a care facility and $11 \%$ in hospital. In case of serious illness, as many as $88 \%$ of respondents would prefer to receive care within the family rather than professional care in an institution (16). On the other hand, Czech families are generally inexperienced in care: $78 \%$ of Czech households had no experience of caring for an elderly person in the last 5-10 years (17).

In line with current Czech legislation (18), various forms of services exist that can be used by caring families. The only service directly designated for family caregivers is respite care. Caregivers may choose between field, ambulant and institutional forms of respite care, such as home help and home assistance, day centres and short term residence of the dependent person at a caring facility. The Act on Health Services (19) further stipulates that health care may be provided in the patient's homes, in the form of home nursing care. Family caregivers can obtain specific information and advice via various websites, and may visit contact centres run by non-governmental organizations such as the Czech Alzheimer Society and the Diaconia of the Evangelical Church of Czech Brethren (ECCB). As part of the "Care at Home" project, numerous training materials have been published and a series of courses has been offered to family caregivers all over the country. A new care coordinator was also piloted at some hospitals to provide support to caregiving families when their family member was discharged from hospital.

Despite all these opportunities, recent research has shown that informal carers feel they receive little support from the public authorities in the Czech Republic $(11,20)$. They report a number of essential problems connected with informal care.

Firstly, financial support for informal care in the Czech Republic is limited and does not cover all caregiving families' needs. There are three forms of financial support available, the first and most significant of which is the care allowance provided to individuals who are dependent on others. The value of this allowance varies according to the individual's level of activity limitation, classified in four bands. The eligible individuals can use it to pay for professional care, such as help at home, day centre or residential home, or may give it to their family caregivers as compensation for their time and effort. Secondly, the state covers compulsory health and social insurance contributions for informal caregivers, in accordance with the law on public health insurance and social insurance. Thirdly, additional contributions towards living costs and mobility expenses are available to disabled persons. All these payments from the state form important living resources for caring families, but still fall short of meeting their needs, making finances one of the greatest barriers to informal caregiving. Research conducted by the National Continuing Education Fund (20) has shown that $40 \%$ of care-giving families have serious financial difficulties.

The practical possibility of providing informal care is also substantially affected by the caregiver's employment situation: many employers do not provide sufficiently flexible working arrangements (such as part time or flexible hours) to enable family caregivers to retain their employment while caring, and the chances to return to the same position with the same employer after a period of caring have also been shown to be slim (20).

There are regional variations in accessibility of services (21). Informal carers do not usually have enough information, skills or support to effectively identify the social and health services they need (11). Moreover, there are long-term problems in the coordination, accessibility and continuity of health and social care $(11,21)$. Community-based services are not yet fully developed in the Czech Republic, and the system does not yet work well. Community-based services like home care, home help and home assistance, day centres, small housing units, or sheltered housing for older people, especially those with dementia, do exist, but the extent to which these facilities are able to cooperate and coordinate their care work is very limited; for example, they are not allowed to share information on clients (11). Hence, they are not flexible in planning and sharing care. According to other research, many informal carers feel exhausted as a result of the care burden. Health problems, social isolation, psychological and physical exhaustion contribute to the breakdown of informal care (17). Action research carried out on informal carers for people with dementia showed that families were exhausted and felt stigmatized - they were losing their friends, feeling ashamed to go out and talk to people, becoming isolated and excluded, and losing their selfesteem and self-worth. On the one hand, they tried to carry on providing care, while on the other hand they felt anxious, helpless, and "caught in a trap"(22). All these findings show that support for caring families, training in caring skills, support to improve informal carers' competences, psychological support and social inclusion for informal carers, as an important part of the integrated and continual system of social and health care in the community, are still missing. A network of various health and social services located and organized in the community is vital (23). 


\section{The Aim of the Research}

This research aimed to describe the situation of active family carers in the Czech Republic in 2014. The approach was based on the assumption that it is beneficial both for dependent persons and their family carers to sustain family care in their natural social environment for as long as possible. The research exercise was designed to identify the carers' needs, priorities, motivations, resources, and barriers to care in order to establish the key factors determining the carers' decisions to transfer their loved ones to institutional care, rather than continue to care for them at home. We wanted to explore the carers' reasons for continuing or terminating family care and measure their subjective levels of exhaustion. These principal dependent variables were then compared with a list of variables including the extent and duration of regular informal care, the care recipient's grade of dependence, location, and gender and age of both the carer and the person cared-for. Also, the carers' determination to continue or terminate family care was compared with the carers' subjective level of exhaustion, and the roles of the wider family and local community were studied.

\section{MATERIALS AND METHODS}

A self-administered questionnaire was used to collect the data. The questionnaire form was developed in digital and print versions. Data were collected between May and November 2014 The questionnaire was sent electronically to 724 family carers on the Diaconia of the Evangelical Church of Czech Brethren's emailing list, and the paper version was provided to participants at courses on lay care held by the Diaconia during the data collection period. The resulting sample of 200 respondents consists of 117 replies collected via the electronic survey and 83 replies collected in printed form. Missing answers below 3\% are not reported, and only valid frequencies are presented in the Tables. Missing answers above 3\% are reported as a separate category and included in the total replies.

The statistical analysis ( $N=200$ respondents) was performed on the first and on the second degree of sorting through per cent and $\chi^{2}$-statistics in contingency tables. Mean values (Likert scale min 1 - max 7) in 2 dependent variables ("What do you think about continuing to care for your family member in his/her home?" and "How exhausted do you feel in relation to the care you have been providing to your family member?") sorted by selected intervening variables (Table 2 ) were evaluated through two-sample t-tests or One-Way ANOVA, respectively, and alternatively by a Kruskal-Wallis test. The statistical procedures were made in IBM SPSS SW (ver. 22.0).

Our respondents were people who had been providing care for a dependent family member. The majority of the respondents $(80 \%)$ were principal carers, while $20 \%$ reported that they had assisted in the care provision alongside the principal carer. Principal carers were significantly older (on average 55 years) than those who assisted in the family care (on average 46.5 years; t-test, $\mathrm{p}<0.001$ ). Our respondents were spread across the Czech Republic, with the exception of one region, and lived in a broad variety of settlements. In this variable we gave priority to respondents' subjective perception of their place of residence over objective criteria such as number of inhabitants. Our respondents were evenly distributed across all main categories of settlements: just over one quarter stated that they lived in the countryside (26\%), $35 \%$ in a town, $27 \%$ in a city, and $12 \%$ in the capital city Prague or in one of the two large regional capitals (Brno, Ostrava).

Most carers were females (89\%) and middle-aged (50-59 years). The carers' ages ranged from $21-84$ years, with the mean age 53 years; male carers were on average 5 years older than female carers. To a lesser extent, females also prevailed among the recipients of care $(63 \%)$. The age of care recipients varied from 12 to 95 years and the mean age was 74.1 years (male care recipients $=69.2$ years, female care recipients $=77.3$ years $)$. $77 \%$ of care recipients were over 70 years old. Unlike male carers, male care recipients were on average 8 years younger than female care recipients.

Approximately half of the carers were employed or self-employed, whereas the other half were pensioners (29\%), housewives $(10 \%)$, or unemployed $(15 \%)$. The most frequent relationship between the carer and care recipient was the child-parent relationship (51\%), and from the gender aspect the most common was the daughter-mother relationship. To a smaller extent caring spouses/ partners $(12.6 \%)$, caring parents $(10 \%)$, and indirect relatives (11\%) were involved. Only rarely sibling care was provided.

Almost two thirds of care recipients $(65 \%)$ shared a home with their carers, while $30 \%$ lived independently. The various degrees of activity limitation were fairly evenly represented among the care recipients. Most were in degrees II, III or IV (24\%, 22\% and $22 \%$, respectively), while the mildest level of dependency was less frequent $(13 \%) .18 \%$ of those in family care did not receive any state financial allowances for care. As concerns health care, $72 \%$ of those in care had been registered for check-ups with their general practitioner within the calendar year.

Overall, our sample has comparable socio-demographic parameters to other Czech empirical surveys in the field $(20,24)$. The fact that almost all regions and types of settlement are represented in this survey is a strong point in particular. However, data on the entire population of family carers is unfortunately not available.

\section{RESULTS}

\section{Reasons for Providing Long-term Family Care}

Lay care in the household is provided in various modalities and intensities. Half of the carers indicated that they provide intensive 7 days/24 hours direct care. Approximately one third (32\%) reported providing direct care 3-5 times weekly (food preparation and assistance, hygiene, housekeeping, shopping, regular supervision, walks) and a substantially smaller group $(18 \%)$ reported carrying out supervision and assistance twice weekly or fewer times.

Family care is a long-term activity. Almost one third of the carers reported having provided care for at least 5 years (32\%). $25 \%$ of carers reported caring for 2 to 5 years and similarly, $24 \%$ of the respondents reported a care duration of 1 to 2 years. Beginners in family care were also represented in our sample (19\%).

The principal factor persuading these respondents to care for their family members was emotional and moral. Feelings of moral duty and love highly dominated above other motivations (Table 1). Other circumstances, such as access to services or the 
involvement of broader family in care, were less significant. The prohibitive cost of social services was only mentioned by $11 \%$ of respondents, and only $5 \%$ of the respondents mentioned the geographical unavailability or low quality of social services as contributing factor to their decision to care for their relative themselves. A small number of respondents (7\%) compensated their own unemployment by financial allowances received for family care (Table 1).

Emotional and moral factors provide fundamental motivation to keep on providing family care; this was noticeably manifested in our sample, with $53 \%$ of respondents saying they wanted to continue to provide care "at any cost". Some respondents mentioned that only their own personal disability or sickness could prevent them from caring for their family member (Fig. 1). Determination to continue with family care was significantly higher among residents in the countryside and towns, and decreased in the larger cities and in Prague (Spearman $\rho, p \leq 0.01$ ), although it remained high (mean value among Prague carers $=3.4$ on a Likert scale of $1-7$ ).

Only a small portion of our respondents (between 12-15\%) had decided to terminate their family care and place the dependent person in a health and social care institution. This decision was most commonly taken as a result of decreasing health condition of the care recipient, a perceived lack of skills in specialized health and social care of the family caregiver, and the caregiver's own poor state of health and exhaustion. Financial reasons and the need for the caregiver to maintain a full time job and earnings were lesser reasons for taking this decision. Other reasons, including low social prestige, lack of respect, time demands, social isolation, and inconvenient housing conditions were also reported, though substantially less frequently.

Family carers often mentioned physical and mental exhaustion as a limiting condition. Almost all of our respondents reported they felt exhausted (94\%), although this exhaustion varied from mild to severe (Fig. 2). The feeling of exhaustion did not correlate with the age or gender of either the carers or the care recipients. No correlation was found, either, between the carer's exhaustion levels and their on-going economic activity.

The carer's level of determination to sustain family care in the future or terminate it was not affected by the age or gender of the carers or persons in care (Table 2). Our assumption that economically active carers would be more prone to terminate family care was not proven. However, as we have already mentioned, carers in Prague were more prone to end their practice of family care, compared to carers in the countryside and smaller towns. With the exception of location, other objective determinants including

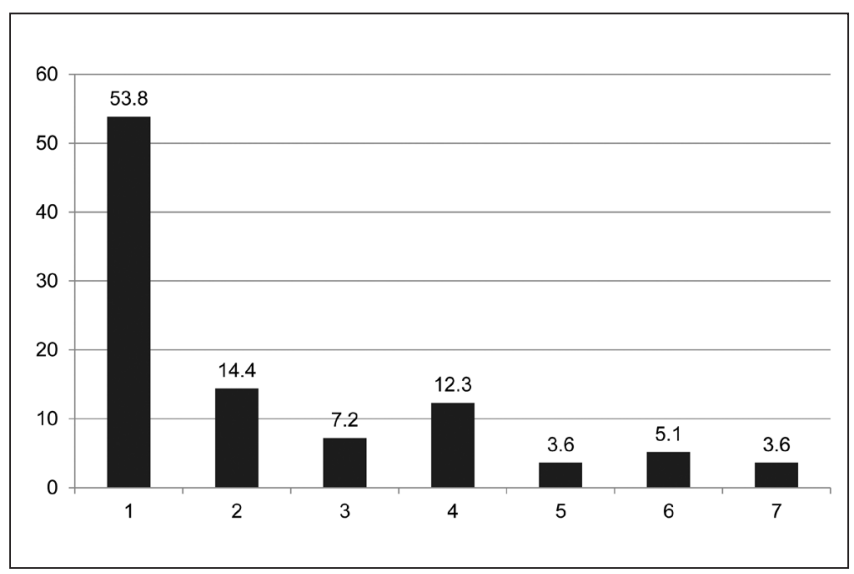

Fig. 1. The continuation of care as viewed by carers (percentage).

1-I am determined to continue caring for my relative "at any cost" ... $7-$ I am determined to terminate home care and place my relative in a care institution.

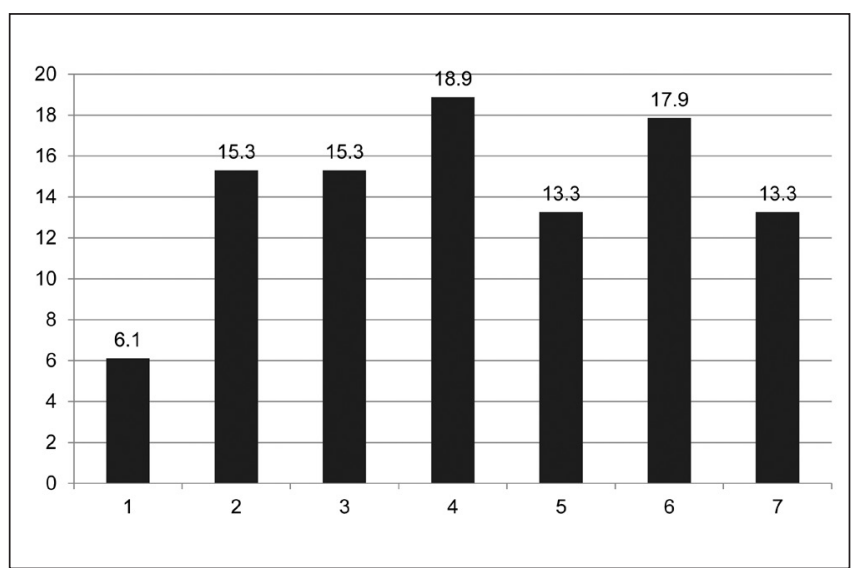

Fig. 2. Perceived exhaustion resulting from care (percentage). $1-$ I feel no exhaustion ... 7 - I feel severely exhausted

work, gender, age, and duration of care were not significant in respect to this decision. Instead, determination to continue with family care was found to be strongly correlated with the carer's subjective perception of the burden and of his/her physical and/or mental exhaustion. Importantly, this correlation was only found to be valid for principal carers. Furthermore, the respondents' determination to continue to care for their relatives was found to be significantly, though inconsistently, affected by the degree of dependency of the person in care, and their respective financial allowances from the social services; it is only weakly and in-

Table 1. What are the main reasons why you care for your family member?

\begin{tabular}{|l|c|}
\hline Multiple response ( $\mathbf{N}=\mathbf{2 9 4}$ ) & $\%$ \\
\hline He/she is the closest person to me, I love him/her, it is a "must" & 51.0 \\
\hline We are a big family, we divide the tasks and as such it is the best solution for us & 12.6 \\
\hline Paid social services are too expensive for us & 11.2 \\
\hline $\begin{array}{l}\text { We use various services like home care nurses, "babysitters", home help assistants, day centres, respite centres, etc., so the care is not } \\
\text { a burden for us }\end{array}$ & 11.2 \\
\hline I am unemployed, my relative's financial allowances for care make up my "salary" and my informal care work will contribute to my pension & 6.8 \\
\hline Social services are not available here or are low quality & 3.7 \\
\hline Another reason & 3.4 \\
\hline
\end{tabular}


Table 2. Determination to continue with care, and exhaustion, in various relations

\begin{tabular}{|c|c|c|c|c|c|c|}
\hline & \multicolumn{2}{|c|}{$\begin{array}{l}\text { Determination to continue with family } \\
\text { care* }\end{array}$} & \multirow{2}{*}{$\begin{array}{c}\begin{array}{c}\text { One-Way ANOVA } \\
\text { or two-sample- } \\
\text { t-test; }\end{array} \\
\text { Kruskal-Wallis test } \\
T(F) ; X^{2}\end{array}$} & \multicolumn{2}{|c|}{$\begin{array}{c}\text { How exhausted do you feel in relation } \\
\text { to the care you have been providing to } \\
\text { your family member?** }\end{array}$} & \multirow{2}{*}{$\begin{array}{c}\begin{array}{c}\text { One-Way ANOVA } \\
\text { or two-sample- } \\
\text { t-test; } \\
\text { Kruskal-Wallis test }\end{array} \\
T(F) ; X^{2}\end{array}$} \\
\hline & Group (N) & Mean (SD) & & Group (N) & Mean(SD) & \\
\hline \multirow[t]{2}{*}{$\begin{array}{l}\text { Caring } \\
\text { responsibility }\end{array}$} & $\begin{array}{l}\text { Principal carer } \\
\quad(N=151)\end{array}$ & $2.14(1.72)$ & \multirow{2}{*}{$\begin{array}{c}T[187]=2.205 \\
(p=0.029) \\
X^{2}[1]=6.044 \\
(p=0.014)\end{array}$} & $\begin{array}{c}\text { Principal carer } \\
\quad(N=153)\end{array}$ & $4.35(1.84)$ & \multirow{2}{*}{$\begin{array}{c}T[188]=1.789 \\
(p=0.075) \\
X^{2}[1]=3.329 \\
(p=0.068)\end{array}$} \\
\hline & $\begin{array}{l}\text { Additional carer } \\
\qquad(\mathrm{N}=38)\end{array}$ & $2.84(1.88)$ & & $\begin{array}{l}\text { Additional carer } \\
\quad(\mathrm{N}=37)\end{array}$ & $3.76(1.74)$ & \\
\hline \multirow[t]{2}{*}{ Gender of the carer } & Female $(N=174)$ & $2.29(1.75)$ & \multirow{2}{*}{$\begin{array}{c}T[192]=0.210 \\
(p=0.834) \\
X^{2}[1]=0.004 \\
(p=0.952)\end{array}$} & Female $(N=173)$ & $4.28(1.82)$ & \multirow{2}{*}{$\begin{array}{c}T[193]=1.133 \\
(p=0.259) \\
X^{2}[1]=1.392 \\
(p=0.238)\end{array}$} \\
\hline & Male $(N=20)$ & $2.20(1.85)$ & & Male $(\mathrm{N}=22)$ & $3.82(1.81)$ & \\
\hline \multirow[t]{2}{*}{ Age of the carer } & $<55$ years $(\mathrm{N}=97)$ & $2.11(1.63)$ & \multirow{2}{*}{$\begin{array}{l}T[189]=1.476 \\
(p=0.142) \\
X^{2}[1]=1.235 \\
(p=0.266)\end{array}$} & $<55$ years $(\mathrm{N}=96)$ & $4.07(1.81)$ & \multirow{2}{*}{$\begin{array}{c}T[190]=1.356 \\
(p=0.177) \\
X^{2}[1]=1.767 \\
(p=0.184)\end{array}$} \\
\hline & 55 years $+(\mathrm{N}=94)$ & $2.49(1.88)$ & & $55+$ years $(N=96)$ & $4.43(1.81)$ & \\
\hline \multirow{2}{*}{$\begin{array}{l}\text { Gender of the } \\
\text { dependent person } \\
\text { in care }\end{array}$} & Female $(N=119)$ & $2.36(1.80)$ & \multirow{2}{*}{$\begin{array}{l}T[191]=0.814 \\
(p=0.417) \\
X^{2}[1]=1.291 \\
(p=0.256)\end{array}$} & Female $(N=120)$ & $4.29(1.79)$ & \multirow{2}{*}{$\begin{array}{c}T[192]=0.434 \\
(p=0.665) \\
X^{2}[1]=0.204 \\
(p=0.651)\end{array}$} \\
\hline & Male $(N=74)$ & $2.15(1.71)$ & & Male $(\mathrm{N}=74)$ & $4.18(1.84)$ & \\
\hline \multirow[t]{2}{*}{$\begin{array}{l}\text { Age of the } \\
\text { dependent person }\end{array}$} & $\begin{array}{l}\text { Less than } 75 \text { years } \\
\qquad(\mathrm{N}=61)\end{array}$ & $2.28(1.79)$ & \multirow{2}{*}{$\begin{array}{c}T[189]=0.064 \\
(p=0.949) \\
X^{2}[1]=0.091 \\
(p=0.763)\end{array}$} & $\begin{array}{l}\text { Less than } 75 \text { years } \\
\qquad(N=63)\end{array}$ & $4.54(1.82)$ & \multirow{2}{*}{$\begin{array}{c}T[190]=1.648 \\
(p=0.101) ; \\
X^{2}[1]=2.717 \\
(p=0.099)\end{array}$} \\
\hline & $76+$ years $(N=130)$ & $2.26(1.71)$ & & $76+$ years $(N=129)$ & $4.09(1.78)$ & \\
\hline \multirow{5}{*}{$\begin{array}{l}\text { Financial allowan- } \\
\text { ces for the } \\
\text { dependent person } \\
\text { (monthly) }\end{array}$} & None $(\mathrm{N}=36)$ & $2.61(2.07)$ & \multirow{5}{*}{$\begin{array}{c}F[4 ; 189]=2.951 \\
(p=0.021) \\
X^{2}[4]=10.345 \\
(p=0.035)\end{array}$} & None $(\mathrm{N}=36)$ & $4.14(1.99)$ & \multirow{5}{*}{$\begin{array}{c}F[4 ; 189]=2.177 \\
(p=0.073) \\
X^{2}[4]=8.352 \\
(p=0.080)\end{array}$} \\
\hline & 800 CZK (N=25) & $1.80(1.38)$ & & $800 \mathrm{CZK}(\mathrm{N}=26)$ & $4.19(1.55)$ & \\
\hline & $4,000 \mathrm{CZK}(\mathrm{N}=44)$ & $2.34(1.58)$ & & $4,000 \mathrm{CZK}(\mathrm{N}=43)$ & $3.65(1.80)$ & \\
\hline & $8,000 \mathrm{CZK}(\mathrm{N}=46)$ & $2.76(2.02)$ & & 8,000 CZK $(N=45)$ & $4.73(1.81)$ & \\
\hline & $12,000 \mathrm{CZK}(\mathrm{N}=43)$ & $1.70(1.32)$ & & $12,000 \mathrm{CZK}(\mathrm{N}=44)$ & $4.43(1.72)$ & \\
\hline \multirow[t]{4}{*}{ Location } & $\begin{array}{l}\text { Countryside } \\
\qquad(N=50)\end{array}$ & $1.78(1.31)$ & \multirow{4}{*}{$\begin{array}{c}F[3 ; 189]=2.943 \\
(p=0.034) ; \\
X^{2}[3]=6.766 \\
(p=0,080)\end{array}$} & $\begin{array}{l}\text { Countryside } \\
\qquad(N=51)\end{array}$ & $4.71(1.88)$ & \multirow{4}{*}{$\begin{array}{c}F[3 ; 190]=2.465 \\
(p=0.064) ; \\
X^{2}[3]=7.716 \\
(p=0.052)\end{array}$} \\
\hline & Town $(N=67)$ & $2.34(1.85)$ & & Town $(\mathrm{N}=68)$ & $4.04(1.76)$ & \\
\hline & City $(N=65)$ & $2.40(1.83)$ & & City $(N=64)$ & $3.95(1.73)$ & \\
\hline & Prague $(\mathrm{N}=11)$ & $3.36(2.16)$ & & Prague $(\mathrm{N}=11)$ & $4.91(2.02)$ & \\
\hline \multirow{2}{*}{$\begin{array}{l}\text { Carer is also } \\
\text { economically } \\
\text { active }\end{array}$} & Yes $(N=90)$ & $2.37(1.75)$ & \multirow{2}{*}{$\begin{array}{c}T[192]=0.650 \\
(p=0.517) \\
X^{2}[1]=1.539 \\
(p=0.215)\end{array}$} & Yes $(N=89)$ & $3.96(1.75)$ & \multirow{2}{*}{$\begin{array}{c}T[193]=1.959 \\
(p=0.052) \\
x^{2}[1]=3.940 \\
(p=0.047)\end{array}$} \\
\hline & No $(N=104)$ & $2.20(1.78)$ & & No $(N=106)$ & $4.46(1.84)$ & \\
\hline \multirow[t]{2}{*}{$\begin{array}{l}\text { Provision of family } \\
\text { care in years }\end{array}$} & $\begin{array}{l}\text { Up to } 5 \text { years } \\
\qquad(N=132)\end{array}$ & $2.44(1.84)$ & \multirow{2}{*}{$\begin{array}{c}T[191]=1.924 \\
(p=0.056) ; \\
X^{2}[1]=3.524 \\
(p=0.060)\end{array}$} & $\begin{array}{l}\text { Up to } 5 \text { years } \\
(N=132)\end{array}$ & $4.00(1.77)$ & \multirow{2}{*}{$\begin{array}{c}T[192]=2.695 \\
(p=0.008) ; \\
X^{2}[1]=7.119 \\
(p=0.008)\end{array}$} \\
\hline & $5+$ years $(N=61)$ & $1.92(1.53)$ & & $5+$ years $(N=62)$ & $4.74(1.84)$ & \\
\hline \multirow{3}{*}{$\begin{array}{l}\text { Feeling of exhaus- } \\
\text { tion due to } \\
\text { family care }\end{array}$} & $\begin{array}{l}\text { Mild or none } \\
\qquad(\mathrm{N}=41)\end{array}$ & $1.68(1.35)$ & $\begin{array}{c}F[2 ; 189]=4.899 \\
\quad(p=0.008)\end{array}$ & & & \\
\hline & Moderate (N=91) & $2.21(1.64)$ & $X^{2}[2]=9.691$ & & & \\
\hline & Severe $(N=60)$ & $2.27(2.06)$ & 0.00 & & & \\
\hline
\end{tabular}

* 1 - I am determined to continue caring for my relative at any cost ... 7 - I am determined to terminate home care and place my relative in a care institution

**1 - no exhaustion ... 7 - severe exhaustion

Significant correlations are marked in bold.

versely influenced by the duration of care in years - "the longer they care the more they wish to continue" - although the feeling of exhaustion is markedly affected by the duration of care, with noticeable borderline between those who had cared for less than 5 years and those who had been caring for longer time. Despite an existing correlation between these feelings of exhaustion and the carer's determination to continue with care, we identified high levels of determination to sustain care even among those who felt exhausted and had been caring for longer than 5 years, especially among those living in the countryside. 


\section{Sources of Support to Family Carers}

As part of the questionnaire, the family carers were asked to assess a list of 10 possible sources of support which could help them to prolong their family care. Of these, greater involvement of medical doctors ranked the highest in their responses (Fig. 3). According to the respondents, the medical care their relatives receive is good but primary care medics should take a more active part in a future model of integrated community based health and social care in terms of home visits, and some coordination of services and counselling. Similarly, better access to information on social services and social benefits and the provision of free nursing care at home were reported as desired resources. Overall, the respondents considered all the possible sources of support to be desirable from the perspective of long-term family care (the mean value was above 4 , which corresponded to the response category "rather important").

Subsequently, the respondents were asked to indicate which factors would help them to continue providing family care; once again, all the factors presented were considered important, however opportunities for short-term and intensive relaxation and release from care ranked the highest (Fig. 4). Involving other family members was considered less important. Similarly, carers did not feel that they need new skills to care. We interpreted this as indicating that they were not aware of the potential improvement of their care with the acquisition of new skills, or that their need was already met in the courses on home help and family care.

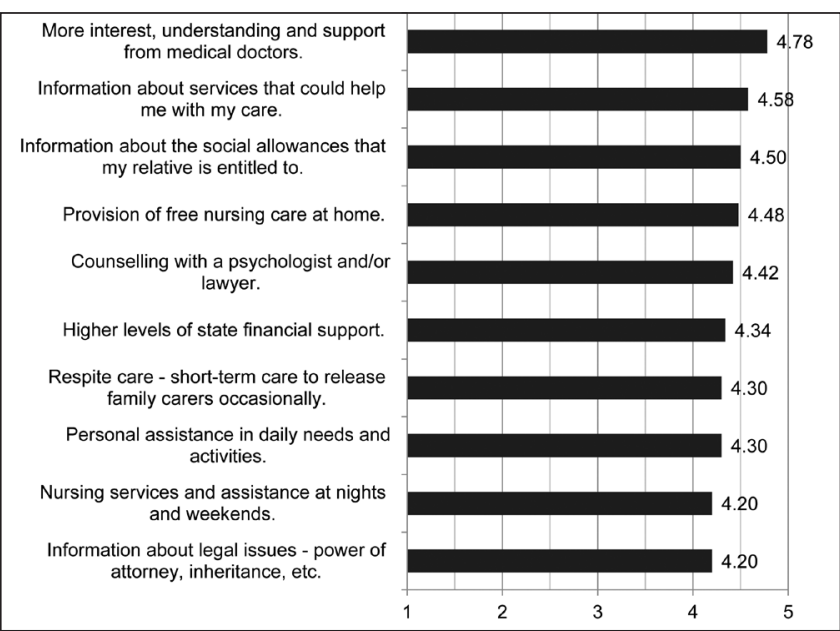

Fig. 3. Which of the following do you find supporting for your care work in the future? $(N=200)$, Likert scale 1-5, $1=$ not at all important, $5=$ very important (mean values).

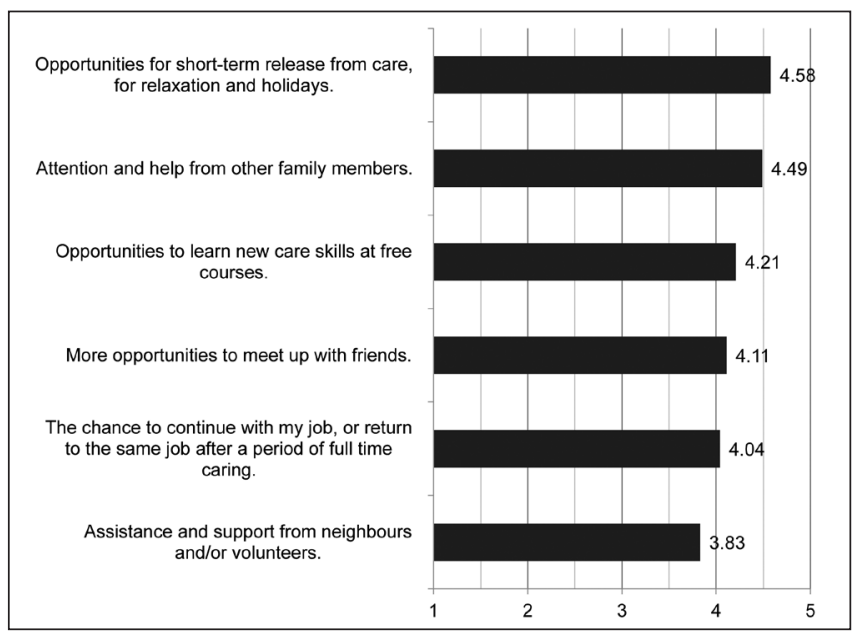

Fig. 4. Would the following make you more likely to continue providing family care? $(N=200)$, Likert scale $1=$ no, not at all, $5=y e s$, definitely (mean values).

Social activities with friends and active work were obviously less relevant as a source of support. It can be explained by the high proportion of pensioners and older carers in our sample. The least important factor in helping carers continue to care was voluntary help and neighbourly assistance.

A further section of our study was dedicated to addressing the hypothetical (or, for some, real) situation in which the respondents as carers could no longer continue caring for their relative. The diversity of the responses in this part of the questionnaire was high, but three trends emerge: institutional care, with or without the active participation of the family carer; extension of the informal caring team to support continued care at home; and home alterations and the installation of specific equipment in household to make long-term home care possible (Table 3).

Socially, our respondents demonstrated a keen interest in participating in self-help associations, in community social events and in social counselling at home; this interest varied regionally, and was highest in Prague (Table 4). Only a small proportion of carers $(14 \%)$ reported being in contact with self-help groups at the time of the questionnaire, but $61 \%$ expressed an interest in participating in such groups in the future (no availability in their area or the carer's lack of free time were the limiting factors). Just under a quarter $(22 \%)$ of respondents stated they did not want to be involved with self-help associations. $28 \%$ had participated with their relative in a social activity or event within the past year, such as memory training reminiscence sessions, physical

Table 3. Possible future solutions if family care is unsustainable

\begin{tabular}{|l|c|}
\hline Multiple response ( $\mathbf{N}=\mathbf{2 7 3}$ ) & $\%$ \\
\hline Place the family member into a good residential home and participate in their care together with the staff there & 23.1 \\
\hline Involve additional helpers, e.g. neighbours, volunteers, nurses, home assistants & 20.9 \\
\hline Make ergonomic and layout modifications at home to make care easier & 19.8 \\
\hline Place the family member into a residential home which will be responsible for their overall care & 15.8 \\
\hline Move into a new home with easier access and make maximum use of care services at home & 9.2 \\
\hline Use day centres for daily care & 6.2 \\
\hline Hand over the responsibility for the care to another family member & 3.7 \\
\hline Something else & 1.5 \\
\hline
\end{tabular}


Table 4. Self-help and other social or community activities

\begin{tabular}{|l|c|}
\hline & Yes (\%) \\
\hline I attend self-help activities and groups & 13.5 (28.6 in Prague) \\
\hline $\begin{array}{l}\text { I would consider attending self-help activities and groups if there were any, but there are none in my area or I do not } \\
\text { have time enough }\end{array}$ & 61.0 \\
\hline I have attended a social activity together with the care recipient this year & 28.1 \\
\hline I would consider attending social activities together with the care recipient & 55.5 \\
\hline I would appreciate home visits from a social worker, to provide help, advice and support & 70.0 \\
\hline
\end{tabular}

exercise, theatre performances, or other cultural events, although the regional variations were once again significant here. The main reason given for non-attendance at such events was the care recipient's bad physical health; in most cases, the carers did not report a lack of opportunities in this field, nor a lack of time or transport.

\section{DISCUSSION AND CONCLUSION}

Our survey has confirmed that family care is not gender equal in practice. Family carers who responded to our survey were mainly middle-aged women, usually daughters caring for a parent; the male carers who responded were largely the spouses. Approximately $50 \%$ of these carers were economically active, juggling a job and their care duties. Most respondents had longterm experience with family care. The key factors motivating them to care for their relative were emotional and moral - feelings of love, responsibility and duty were dominant. This corresponds with Graham's theory of a "labour of love" (25), where caring includes not only physical work, but also the primary carer's interest in and emotional relation with the loved-one he/she cares for. This "labour of love" is closely connected to human existence and human basic needs (17). According to our respondents, social services are available across the country, but are often too expensive or inflexible to individual needs (no availability in weekends, nights, etc.). It is recommendable to address the issue of exhaustion and tiredness of the family caregivers soon to sustain the family care in the long-term. Though, the feeling of exhaustion per se did not correlate with determination to continue care since even the most exhausted carers expressed a desire to keep up their family care. The decision to terminate family care was most commonly motivated by the deteriorating health of the individuals in care and their need for highly qualified and permanent nursing care.

Our respondents did not recognize volunteers and neighbours as an important source of care support. This may be due to the respondents' lack of experience with volunteers and neighbours helping in their private homes. Involving such helpers on the basis of neighbourhood could better meet the carers' needs for short-term release from their duties, enabling them to relax, which cannot always be easily provided by professional or paid services. On the other hand, the respondents manifested a strong interest in activities organized by the community, in particular activities which carers can attend together with the care recipients. Home social counselling is another desired and possibly efficient tool of the integrated social and health care system in community. The role of the community social worker, who would visit older adults living in community to actively identify their needs and coordinate community health and social services for the aged population was demanded by our respondents.

A remarkably high percentage of the carers who participated in our study were heavily determined to continue to care for their relative, at any cost. The strength of the moral commitment indicates that the family or personal decision is fundamental for the family care. This determination to continue with care is stronger among those living in the countryside and weaker among those living in cities. Living conditions in the cities (generally smaller flats) are one of the limitations behind, as well as a different structure of work/life opportunities and ambitions. Carers in Prague have specific needs and live in different conditions, hence combining family care and economic activity is less common in the capital city. Furthermore, in the bigger cities, residents tend to be more highly qualified, earn more, work more intensively, and are therefore not adequately "compensated" when becoming a family carer (26).

Our findings are similar to those of other Czech and international surveys and confirm that there is a growing demand for innovations in social service provision in the Czech Republic, which would support at-home family care through the greater involvement of medical doctors, increased provision of community activities and services, as a part of an integrated community based system of health and social care.

\section{Acknowledgement}

This article is part of a project at the Diaconia of the Evangelical Church of Czech Brethren which is supported by a grant from Switzerland through the Swiss Contribution to the enlarged European Union. We are grateful to Ann Burton who has supervised the English translation.

\section{Conflict of Interests}

None declared

\section{Adherence to Ethical Recommendations}

The questionnaire survey on which this article is based was carried out anonymously and fully respected respondents' privacy and autonomy.

\section{REFERENCES}

1. Glenn EN. Creating a caring society. Contemp Sociol [Internet]. 2000 [cited 2015 May 12];29(1):84-94. Available from: https://Caringlabor. Wordpress.Com/2011/01/25/Evelyn-Nakano-Glenn-Creating-A-CaringSociety/.

2. Fine MD. A caring society? Care and the dilemmas of human service in the 21st century. New York: Palgrave Macmillan; 2007.

3. Bowlby J. Attachment and loss. New York: Basic Books; 1969.

4. Goffman E. Asylums: essays on the social situation of mental patients and other inmates. New York (USA): Doubleday Anchor; 1961. 
5. King RD, Raynes NV, Tizard J. Patterns of residential care: sociological studies in institutions for handicapped children. London: Routledge and Kegan Paul; 1971.

6. Kitwood TM. Dementia reconsidered: a person comes first. Buckingham: Open University Press; 1997.

7. Weinstein RM. Goffman's asylums and the social situation of mental patients. Orthomol Psychiatry [Internet]. 1982 [cited 2015 Aug 20]; 11(4): 267-274. Available from: http://orthomolecular.org/library/jom/1982/ pdf/1982-v11n04-p267.pdf.

8. Pavolini E, Ranci C. Restructuring the welfare state: reforms in long-term care in western European countries. J Eur Soc Policy. 2008;18(3):246-59.

9. Evashwick CJ. The continuum of long-term Care. New York (USA): Thomson Delmar Learning; 2005.

10. Colombo F, et al. Help wanted? Providing and paying for long-term Care. OECD Health Policy Studies [Internet]. OECD Publishing; 2011 [cited 2015 May 12]. Available from: https://www.oecd.org/els/healthsystems/47836116.pdf.

11. Kotrusová M, Janečková $H$, Angelovská $O$, Dobiášová K. The need for health and social services for seniors in Prague. Reflection of the current situation. Zdravotnictví v ČR [Internet]. 2012 [cited 2015 March 1]; XV(2): 11-9. Available from: http://www.zdravcr.cz/archiv/zcr-2-2012. pdf. (In Czech.)

12. Futurage: a road map for European ageing research [Internet]. Sheffield (UK): Futurage; 2011 [cited 2015 May 12]. Available from: http://www. futurage.group.shef.ac.uk/.

13. Miranda V. Cooking, caring and volunteering: unpaid work around the world. OECD social, employment and migration working papers, no. 116 [Internet]. OECD Publishing: 2011 [cited 2015 March 1]. Available from: http://dx.doi.org/10.1787/5kghrjm8s142-en.

14. Kuchařová V, Rabušic L, Ehrenbergerová L. Life in old age: empirical research report [Internet]. Prague: Research Institute for Labour and Social Affairs; 2002 [cited 2015 March 1]. Available from: http://praha. vupsv.cz/fulltext/zivest.pdf. (In Czech.)

15. Svobodová K. Intergenerational mutual help and provision of care to seniors. Demografie [Internet]. Demografické informační centrum; 2008 [cited 2014 Nov 18]. Available from: http://www.demografie.info/?cz_detail_clanku\&artclID=571. (In Czech.)

16. Dying and the terminal care II. Final report [Internet]. Prague: Going Home; 2013 [cited 2015 May 12]. Available from: http://www.umirani. cz/sites/default/files/custom-files/cesta-domu-zprava-umirani-a-pece-onevylecitelne-nemocne-2013.pdf. (In Czech.)
17. Jeřábek H. Family care for seniors as a 'labour of love' - new arguments. Sociol Cas. 2009;45(2):243-66. (In Czech.)

18. Act No. 108 of March 14, 2006, on social services. Sbírka zákonů ČR. 2006 March 31;Pt 37:1257-89. (In Czech.)

19. Act No. 372 of December 8, 2011, on healthcare services and conditions for providing them (Act on healthcare services). Sbírka zákonů ČR. 2011 Dec 8;Pt 131:4730-801. (In Czech.)

20. Geissler H, Holeňová A, Horová T, Jirát D, Solnářová D, Schlanger J, et al. Final analytical report on the current situation and needs of caregivers and on existing barriers in provision of informal care in the Czech Republic. Prague: National Continuing Education Fund; 2015. (In Czech.)

21. Kalvach Z, et al. Development of the community system of the integrated supportive services [Internet]. Prague: Diakonie ČCE; 2014 [cited 2016 Feb 18]. Available from: http://www.diakonie.cz/res/data/013/001859. pdf. (In Czech.)

22. Janečková H. Assessment of reminiscence group work with families caring for a person with dementia. In: Štěpánková H, Šlamberová R, editors. Proceedings of the 2nd Gerontological Interdisciplinary Conference; 2014 Oct 24-25; Prague [Internet]. Prague: Charles University, Third Faculty of Medicine; 2014 [cited 2015 May 12]. p. 64-74. Available from: http:// www.konferencestarnuti.cz/files/Starnuti 2014 sbornik.pdf.

23. Uhlíŕová B. Caregivers and their role in the transformation of social services. Sociální práce. 2013;13(1):29-33. (In Czech.)

24. Support to family caregivers caring for seniors: survey of opinions on the needs and problems of family caregivers caring for subjects of 60 years and over in the realm of social services in Prague 7 and 8 [Internet]. Prague: City District Prague 8; 2012 [cited 2014 Aug 20]. Available from: http://www.praha8.cz/file/zK11/zprava-pecujici-fin.pdf. (In Czech.)

25. Graham H. Caring: a labour of love. In: Finch J, Groves D, editors. A labour of love: women, work and caring. London (UK): Routledge and Kegan Paul; 1983. p. 13-30.

26. Klímová Chaloupková J. Informal family care: sociodemographic characteristics of the caregivers. Data a výzkum - SDA Info. 2013;7 (2):107-23. (In Czech.)

Received June 12, 2015 Accepted in revised form November 15, 2016 